\title{
Penerapan Metode Struktural Analitik Sintetik untuk Meningkatkan Keterampilan Menulis Permulaan Siswa Sekolah Dasar
}

\author{
Cornelia Amanda Naitili ${ }^{1}$, I Made Suardana ${ }^{2}$, M. Ramli ${ }^{3}$ \\ ${ }^{1}$ Pendidikan Dasar-Universitas Negeri Malang \\ ${ }^{2}$ Keguruan Sekolah Dasar dan Prasekolah-Universitas Negeri Malang \\ ${ }^{3}$ Bimbingan dan Konseling-Universitas Negeri Malang
}

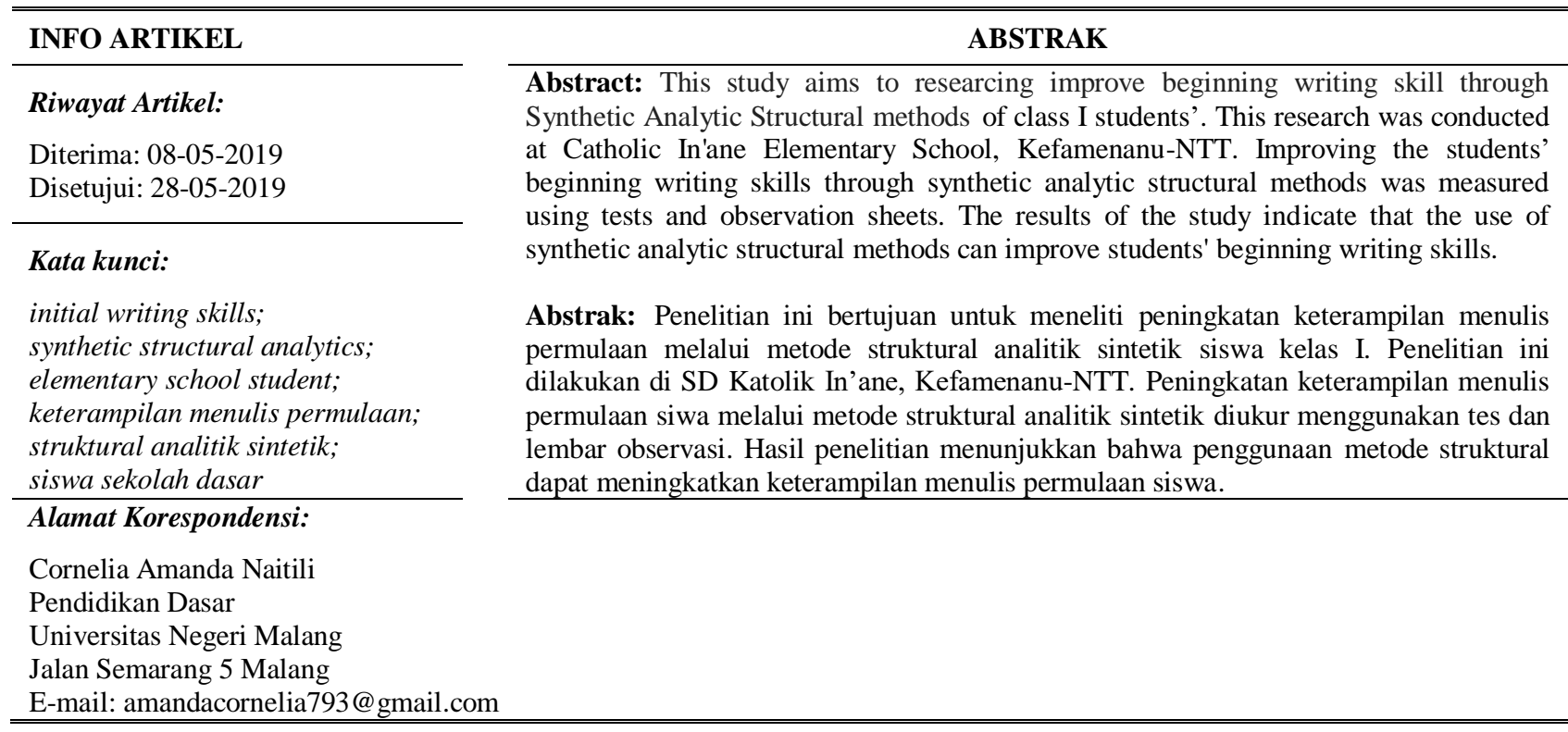

Menulis merupakan kegiatan dalam berkomunikasi dengan manusia lain untuk menyampaikan gagasan dalam bentuk pesan melalui bahasa tulis atau lambang bahasa. Menulis juga merupakan Suatu kegiatan penyampaian pesan yang digunakan seseorang sebagai alat komunikasi berupa ungkapan-ungkapan pikiran, perasaan dan ide-idenya yang diungkapkan menggunakan bahasa tulisnya sendiri (Dalman, 2016). Proses menulis tidak mungkin datang tanpa adanya suatu latihan sehingga tempat pelatihan awal dimulai dari tingkat pendidikan dasar. Siswa diharapkan mampu menyampaikan ide dan gagasannya kepada orang lain senigga kemampuan menulis siswa harus diajarakan dan dikuasai dari siswa mulai memasuki usia sekolah (Saddhono \& Slamet, 2014)). Pembelajaran keterampilan menulis di sekolah dasar dimulai dari kelas I yakni pembelajaran menulis permulaan. Keterampilan menulis permulaan wajib dikuasai oleh siswa sebagai dasar mempelajari dan menguasai ilmu pengetahuan lain di jenjang berikutnya. Penguasaan keterampilan menulis sangat memengaruhi kemampuan siswa, terlebih lagi kemampuan kognitif dan psikomotorik siswa (Hidayah, 2016).

Pembelajaran menulis permulaan di kelas I lebih diorientasikan pada kemampuan yang bersifat mekanik. Artinya siswa dilatih untuk menuliskan lambang-lambang tulis yang jika dirangkaikan dalam sebuah stuktur maka lambang-lambang itu menjadi bermakna (Solchan.,dkk, 2014). Pada menulis permulaan siswa diharapkan untuk dapat memproduksi tulisan yang dapat dimulai dengan tulisan eja. Contoh tulisan e, d, f, k, j, dan dapat berupa suku kata seperti su-ka, ma-ta, ha-rus, lu-ka serta dalam bentuk kalimat sederhana. Menulis permulaan (dengan huruf kecil) di kelas rendah siswa sekolah dasar tujuannya adalah agar siswa memahami cara menulis permulaan dengan ejaan yang benar dan mengomunikasikan ide/pesan secara tertulis, materi pelajaran menulis permulaan dikelas rendah sekolah dasar disajikan secara bertahap dengan menggunakan pendekatan huruf, suku kata, kata-kata atau kalimat (Mustikowati, 2016).

Wadah pelatihan awal menulis permulaan dimulai dari tingkat pendidikan dasar. Namun, kenyataan di lapangan masih ditemukan banyak masalah tentang pembelajaran menulis mulai dari penulisan huruf, kata, kalimat maupun narasi serta ejaan yang benar. Dengan demikian, maka guru perlu mencari solusi terbaik untuk meningkatkan keterampilan menulis tersebut. Oleh karena itu, metode pembelajaran harus dipilih dan dikembangkan untuk meningkatkan aktivitas dan kreativitas siswa dalam hal menulis. Dengan kata lain, penggunaan metode yang tepat akan turut menentukan efektivitas dan efisiensi pembelajaran. Hal ini akan membantu peserta didik dalam mencapai tujuan pembelajaran (Rusman, 2014). Jadi, jelaslah bahwa metode mengajar dapat memengaruhi belajar. Agar siswa dapat belajar dengan baik, maka perlu dipilih metode pembelajaran yang tepat, efisien, dan efektif. Salah satu penyebab rendahnya hasil belajar bahasa siswa saat ini, khususnya pada jenjang Sekolah Dasar adalah 
pembelajaran bahasa yang dilakukan masih secara konvensional, pembelajaran masih bersifat guru sentris. Guru sering ditempatkan sebagai sumber utama pengetahuan dan berfungsi sebagai peneransfer pengetahuan. Selain itu, guru kurang kreatif dalam menerapkan berbagai metode pembelajaran yang menyenangkan sehingga siswa merasa senang dan antusias. Akibatnya, siswa menjadi pasif, dan minat siswa terhadap bahasa tidak berkembang dengan baik yang pada akhirnya menyebabkan penguasaan siswa terhadap bahasa menjadi rendah. Padahal proses belajar mengajar adalah suatu kegiatan antara guru dan siswa serta komunikasi timbal balik yang berlangsung dalam suasana edukatif untuk mencapai tujuan belajar (Patty, 2015).

Berdasarkan hasil observasi awal yang dilakukan pada pembelajaran Bahasa Indonesia di kelas I SD Katolik In'ane ditemukan banyak ssiwa yang mengalami kesulitan dalam menulis permulaan sehingga memengaruhi hasil belajar yang diperoleh siswa. Kesulitan yang dialami siswa dalam menulis permulaan yaitu siswa terlalu lambat dalam menulis, membuat tulisan terbalik seperti pada huruf $\mathrm{b}, \mathrm{d}, \mathrm{g}, \mathrm{h}, \mathrm{n}, \mathrm{p}, \mathrm{w}, \mathrm{m}, \mathrm{u}$, dan tidak mampu untuk merangkai huruf menjadi suku kata, kata maupun menjadi kalimat yang utuh. Hal ini disebabkan karena dalam pembelajaran menulis permulaan, guru kurang inovatif sehingga siswa kurang leluasa menyampaikan ide-idenya dan lebih banyak bermain tidak berusaha untuk belajar sungguhsungguh. Contohnya, saat mengajar menulis, siswa hanya diajarkan dengan cara tradisional yaitu menjiplak tulisan guru yang ditulis pada lembar buku siswa. Selama peneliti melakukan observasi, ternyata juga ditemui bahwa dalam pembelajaran, siswa tidak difasilitasi dengan Lembar Kerja Siswa. Hal ini diakui oleh guru kelas, bahwa perangkat pembelajaran yang dibuat hanya untuk memenuhi tuntutan kurikulum. Guru ketika mengajar selalu mengandalkan pengalamannya, daripada mengikuti langkahlangkah yang termuat dalam perangkat pembelajaran. Perangkat pembelajaran yang disiapkan guru hanyalah sebatas Rencana Pelaksanaan Pembelajaran dan silabus saja.

Permasalahan tentang keterampilan menulis siwa yang rendah dapat diatasi dengan penerapan salah satu metode pembelajan yaitu metode Struktural Analitik Sintetik. Metode Struktural Analitik Sintetik merupakan salah satu metode yang digunakan dalam pembelajaran menulis permulaan yang menggunakan struktur kalimat sebagai titik tolaknya. Metode Struktural Analitik Sintetik adalah suatu metode yang diawali secara keseluruhan yang kemudian dari keseluruhan itu dicari dan ditemukan bagian-bagian tertentu dan fungsi-fungsi bagian itu. Setelah mengenal bagian-bagian serta fungsinya kemudian dikembangkan pada struktur totalitas seperti penglihatan semula (Lisnawati \& Muthmainah, 2019). Metode Struktural Analitik Sintetik dapat merangsang anak didik untuk melibatkan diri secara aktif, karena anak didik selain mendengarkan, melafalkan, dan mencatat, juga mempergunakan alat peraga. Proses pembelajaran menggunakan metode Struktural Analitik Sintetik diawali dengan menampilkan stuktur kalimat secara utuh dahulu, lalu kalimat itu di analisis dan pada akhirnya di kembalikan pada kalimat bentuk semula (Dewi, 2018). Langkah-langkah pembelajaran metode SAS yang yaitu (1) struktural: pembelajaran menulis permulaan dengan metode Struktural Analitik Sintetik diawali dengan menampilkan dan memperkenalkan sebuah kalimat utuh, (2) analitik: kalimat utuh yang dijadikan dasar untuk pembelajaran menulis permulaan diuaraikan ke dalam satukesatuan bahasa yang kebih kecil yang disebut kata. Proses penganalisisan atau penguraian ini terus berlanjut hingga pada wujud satuan bahasa terkecil yang tidak bisa diuraikan lagi yaitu huruf, (3) sintetik: siswa dibimbing untuk melakukan sintetik (merangkai). Siswa merangkai lagi dari huruf-huruf menjadi suku kata, suku-suku kata menjadi kata dan kata-kata menjadi kalimat. Dengan demikian melalui proses sintesis ini siswa akan menemukan kembali wujud struktur semula yaitu sebuah kalimat utuh (Solchan, dkk, 2014).

Proses pembelajaran menulis permulaan menggunakan metode Struktural Analitik Sintetik dilakukan pada siswa Kelas I SD Katolik In'ane. Tahap-tahap pembelajaran menulis permulaan melalui metode Struktural Analitik Sintetik yang digunakan dalam penelitian ini diadaptasi dari Solchan.,dkk (2014) sebagai berikut: (1) guru menyajikan gambar/video, (2) siswa mengidentifikasi gambar/video, (3) guru bersama siswa melakukan permainan, (4) guru memberikan contoh kalimat, (4) guru menggunakan kartu huruf untuk memberikan contoh kepada siswa menguraikan kalimat menjadi kata, suku kata dan huruf, (5) siswa mnguraikan ka menjadi kata, suku kata dan huruf menggunakan kartu huruf, (6) guru memberikan contoh merangkai huruf menjadi suku kata, kata dan kalimat menggunakan kartu huruf, (6) siswa merangkai huruf menjadi suku kata, kata dan kalimat, (7) siswa latihan menulis menghubungkan huruf putus-putus, (8) siswa mengerjakan lembar kerja siswa.

\section{METODE}

Penelitian ini dilaksanakan di SD Katolik In'ane, kecamatan Biboki Moenleu, Kabupaten Timor tengah Utara, Kupang-NTT pada semester ganjil Tahun Pelajaran 2018-2019. Subyek penelitian ini adalah kelas I dengan jumlah siswa 25 orang yang terdiri dari 13 siswa laki-laki dan 12 siswa perempuan. Data, sumber data, instrumen dan teknik pengumpulan data yang digunakan dalam penelitian ini terangkum pada tabel 1 .

Teknik analisis data yang digunakan dalam penelitian tindakan ini ialah analisis data deskriptif Miles dan Huberman (dalam Sugiyono, 2016) meliputi (1) reduksi data, (2) penyajian data, dan (3) penarikan kesimpulan. Analisis data dilakukan terhadap keterlaksanaan kegiatan guru dan siswa dalam pembelajaran menulis permulaan melalui metode Struktural Analitik Sintetik dan keterampilan menulis permulaan siswa. Keberhasilan penelitian tindakan ini diketahui pada akhir siklus dengan melihat hasil dari tindakan dalam penggunaan metode Struktural Analitik Sintetik untuk meningkatkan kemampuan menulis permulaan siswa kelas I SDK In'ane. Kriteria keberhasilan tindakan dijabarkan pada tabel 2.

Tabel 1. Data, Sumber Data, Instrumen, dan Teknik Pengumpulan Data 


\begin{tabular}{|c|c|c|c|}
\hline Data & Instrumen & Teknik Pengumplan Data & $\begin{array}{l}\text { Sumber } \\
\text { Data }\end{array}$ \\
\hline $\begin{array}{l}\text { Keterlaksanaan kegiatan mengajar guru } \\
\text { dan keterlaksanaan kegatan belajar siswa } \\
\text { melalui penerapan metode struktural } \\
\text { analitik sintetik }\end{array}$ & $\begin{array}{ll}\text { 1. } & \text { RPP } \\
\text { 2. } & \text { Lembar panduan observasi } \\
& \text { keterlaksanaan kegiatan mengajar guru } \\
\text { 3. } & \text { Lembar panduan keterlaksanaan } \\
& \text { kegiatan belajar siswa } \\
\end{array}$ & Dokumen dan observasi & $\begin{array}{l}\text { Guru dan } \\
\text { Siswa }\end{array}$ \\
\hline Kemampuan menulis permulaan & Soal & Tes tulis & Siswa \\
\hline $\begin{array}{l}\text { Persepsi guru dan siswa tentang penerapan } \\
\text { metode struktural analitik sintetik }\end{array}$ & Panduan wawancara & Wawancara & $\begin{array}{l}\text { Guru dan } \\
\text { siswa }\end{array}$ \\
\hline
\end{tabular}

(Sumber: Olahan peneliti adaptasi dari Bua, 2016)

Tabel 2. Kriteria Keberhasilan Tindakan

\begin{tabular}{|c|c|c|c|}
\hline No & Aspek & Sub Aspek & $\begin{array}{l}\text { Pencapaian Rata-rata } \\
\text { Kelas }\end{array}$ \\
\hline 1 & $\begin{array}{l}\text { Penerapan metode SAS berbantuan } \\
\text { media gambar }\end{array}$ & $\begin{array}{l}\text { Keterlaksanaan pembelajaran mengunakan metode Struktural } \\
\text { Analitik Sintetik }\end{array}$ & 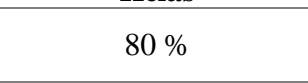 \\
\hline \multirow{3}{*}{2} & \multirow{3}{*}{ Keterampilan Menulis Permulaan } & Kerapihan tulisan & \multirow{3}{*}{$80 \%$} \\
\hline & & Ketepatan tulisan & \\
\hline & & Kelengkapan tulisan & \\
\hline
\end{tabular}

(Sumber: Olahan peneliti adaptasi dari Bua, 2016)

Penelitian ini menggunakan rancangan penelitian tindakan kelas (Classroom Action Research) sebagai rancangan penelitian berdaur ulang (siklus). Model yang akan digunakan dalam penelitian tindakan kelas ini adalah model yang dikembangkan Kemmis., dkk (2014) tiga tahapan, yaitu (1) plan, (2) act dan observe, dan (3) reflecting.

\section{HASIL}

Hasil analisis data yang dilakukan peneliti berupa pembelajaran keterampilan menulis permulaan melalui metode Struktural Analitik Sintetik dan peningkatan keterampilan menulis permulaan melalui metode SAS. Hasil analisis data diperoleh berdasarkan hasil observasi dan tes terhadap kegiatan pembelajaran menulis permulaan dengan menggunakan metode Struktural Analitik Sintetik yang dilakukan dalam tiga siklus. Pembelajaran pada siklus I terdiri dari empat pertemuan dengan materi yang berbeda pada setiap pertemuan. Pada pertemuan pertama, siswa belajar tentang kosakata dan ungkapan perkenalkan diri (nama) dengan media pembelajaran yang digunakan yaitu video perkenalan diri dan kartu huruf. Pada pertemuan kedua, siswa belajar tentang kosakata dan ungkapan perkenalkan diri (umur) dengan media pembelajaran yang digunakan yaitu video perkenalan diri dan kartu huruf. Pada pertemuan ketiga, siswa belajar tentang kosakata dan ungkapan perkenalkan diri (jenis kelamin) dengan media pembelajaran yang digunakan yaitu gambar tugas laki-laki dan perempuan serta kartu huruf. Pada pertemuan keempat, siswa belajar tentang kosakata dan ungkapan perkenalkan diri (kesukaan) dengan media pembelajaran yang digunakan yaitu video jenis hobi. Kegiatan pembelajaran pada setiap pertemuan dilakukan berdasarkan tiga tahap pembelajaran, yaitu tahap pendahuluan, tahap inti, dan tahap penutup.

Kegiatan pembelajaran yang dilakukan pada tahap pendahuluan, meliputi (1) guru memberi salam untuk membuka pelajaran, (2) guru mengajak siswa berdoa untuk mengawali pembelajaran, (3) guru melakukan mengecek kehadiran siswa, (4) guru mengajak siswa menyanyikan lagu sambil memperagakan gerak dalam lagu, (5) guru melakukan apersepsi dan (6) guru menyampaikan kompetensi yang akan dicapai dalam pembelajaran. Selanjutnya kegiatan pembelajaran yang dilakukan pada tahap inti meliputi (1) Guru menyajikan gambar/video kemudian Siswa mengidentifikasi gambar/video yang ditampilkan, (2) Siswa melakukan permainan dengan bantuan guru, (3) guru memberikan contoh sebuah kalimat yang dipilih berdasarkan kalimat perkenalan siswa yang diungkapkan siswa melalui permainan (struktural), (4) guru menggunakan kartu huruf untuk memberikan contoh menguraikan kalimat menjadi kata, suku kata dan huruf (analitik) dan merangkai kembali huruf menjadi suku kata, kata dan kalimat seperti semula (sintetik), (5) setelah memberikan contoh, guru membantu dan membimbing siswa untuk menguraikan kalimat menjadi kata, suku kata dan huruf kemudian merangkai kembali huruf menjadi suku kata, kata dan kalimat seperti yang dicontohkan, dan (6) siswa latihan menulis dengan menghubungkan huruf putus-putus kemudian siswa mengerjakan lembar kerja siswa yang disediakan guru. Pada kegiatan penutup, guru memberikan pujian dan reward kepada siswa yang aktif dalam pembelajaran. Selanjutnya, guru bersama siswa melakukan refleksi terhadap pembelajaran, kemudian menyimpulkan materi pembelajaran. Setelah itu, guru memotivasi sisw auntuk belajar menulis di rumah. Kegiatan pembelajaran diakhiri dengan doa dan salam. 
Kegiatan pembelajaran yang dilakukan dalam setiap pertemuan pada siklus I cukup berjalan dengan lain, meskipun masih terdapat kekurangan yang ditemukan dalam pembelajaran. Misalnya apersepsi yang dilakukan oleh guru pada tahap pendahuluan belum maksimal, video yang ditampilan kurang jelas dan terlalu cepat, beberapa siswa masih belum mampu untuk melakukan kegiatan analisis dan sintetik karena alokasi waktu yang kurang. Serta siswa juga kurang tertib sehingga menggangu kelancaran proses pembelajaran. Selain itu, siswa belum mampu menuliskan umurnya karena tidak mengenal setiap huruf dalam kata yang dituliskan, gambar yang ditampilkan berukuran terlalu kecil serta siswa belum mampu mengenal huruf dengan baik sehingga beberapa siswa sering membuat tulisan terbalik. Berdasarkan kekurangan yang ditemukan maka guru melakukan perbaikan pembelajaran pada siklus II.

Pembelajaran pada siklus I terdiri dari empat pertemuan dengan materi yang berbeda pada setiap pertemuan. Pada pertemuan pertama, siswa belajar tentang kosakata dan ungkapan perkenalan keluarga (ayah) dengan media pembelajaran yang digunakan, yaitu gambar sebuah keluarga, gambar ayah dan kartu huruf. Pada pertemuan kedua, siswa belajar tentang kosakata dan ungkapan perkenalan keluarga (ibu) dengan media pembelajaran yang digunakan yaitu gambar ibu dan kartu huruf. Pada pertemuan ketiga, siswa belajar tentang kosakata dan ungkapan perkenalan keluarga (kakak) dengan media pembelajaran yang digunakan yaitu gambar kakak-adik serta kartu huruf. Pada pertemuan keempat, siswa belajar tentang kosakata dan ungkapan perkenalan keluarga (adik) dengan media pembeljaran yang digunakan yaitu gambar adik. Tahapan pembelajaran yang dilakukan dalam setiap pertemuan pada siklus II sama halnya dengan yang dilakukan pada siklus I. Kegiatan pembelajaran pada siklus II sudah lebih baik dari pembelajaran pada siklus I, meskipun begitu masih terdapat kekurangan yang ditemukan dalam proses pembelajaran. Misalnya diantaranya beberapa siswa masih belum lancar dalam menulis dan tulisan yang dibuat tidak rapi, siswa yang menulis kalimat tidak lengkap karena siswa kesulitan untuk merangkai huruf menjadi suku kata, suku kata kenjadi kata hingga sebuah kalimat yang utuh, beeberapa siswa kurang aktif dalam kegiatan tanya jawab serta guru yang terlalu fokus untuk membimbing siswa tertentu menulis sehingga siswa lain belum mendapat kesempatan untuk dibimbing. Berdasarkan kekurangan yang ditemukan maka guru melakukan perbaikan pembelajaran pada siklus III.

Pembelajaran pada siklus III juga terdiri dari empat pertemuan dengan materi yang berbeda pada setiap pertemuan. Pada pertemuan pertama, siswa belajar tentang kosakata dan ungkapan perkenalan orang-orang di sekitar tempat tinggal (tetangga bagian kiri). Pertemuan kedua, siswa belajar tentang kosakata dan ungkapan perkenalan orang-orang di sekitar tempat tinggal (tetangga bagian kanan). Pada pertemuan ketiga, siswa belajar tentang kosakata dan ungkapan perkenalan orang-orang di sekitar tempat tinggal (tetangga bagian depan). Pada pertemuan keempat, siswa belajar tentang kosakata dan ungkapan perkenalan orang-orang di sekitar tempat tinggal (tetangga bagian belakang). Media pembelajaran yang digunakan dalam setiap pertemuan yaitu gambar rumah tetangga dan kartu huruf. Tahapan pembelajaran yang dilakukan dalam setiap pertemuan pada siklus III sama halnya dengan yang dilakukan pada siklus I dan II. Kegiatan pembelajaran menulis permulaan melalui metode Struktural Analitik Sintetik mengalami peningkatan yang sudah makasimal pada siklus III. Meskipun demikian, guru harus terus memperbaiki kegiatan pembelajaran dengan mengacu pada kekurangan-kekurangan yang terjadi pada pembelajaran sebelumnya. Guru harus memiliki banyak strategi dalam melaksanakan pembelajaran. Guru juga harus menggunakan media pembelajaran yang efektif dan efisien untuk menarik minat dan perhatian siswa dalam mengikuti pembelajaran.

Kegiatan pembelajaran yang dilakukan guru dari siklus I-III dapat meningkatkan keterampilan menulis permulaan siswa melalui metode Struktural Analitik Sintetik. Hasil pembelajaran keterampilan menulis permulaan melalui metode Struktural Analitik Sintetik dibedakan menjadi dua, yaitu evaluasi proses dan evaluasi hasil. Evaluasi proses berupa hasil observasi aktivitas guru dan siswa dalam pembelajaran menulis permulaan melalui metode Struktural Analitik Sintetik. Sementara itu, evaluasi hasil berupa hasil penilaian keterampilan menulis permulaan siswa melalui metode Struktural Analitik Sintetik. Hasil observasi aktivitas guru dan siswa serta hasil penilaian keterampilan menulis permulaan siklus I-III dapat dilihat pada tabel 3,4 , dan 5 .

Tabel 3. Hasil Observasi Aktivitas Guru dalam Pembelajaran Menulis Permulaan

\begin{tabular}{lccc}
\hline \multirow{2}{*}{\multicolumn{1}{c}{ Tahap Pembelajaran }} & \multicolumn{3}{c}{ Penilaian Aktivitas Guru } \\
\cline { 2 - 4 } & Siklus I & Siklus II & Siklus III \\
\hline Tahap Pendahuluan & $71.88 \%$ & $81.25 \%$ & $93.75 \%$ \\
\hline Tahap Inti & $66.25 \%$ & $81.25 \%$ & $85.00 \%$ \\
\hline Tahap Penutup & $69.35 \%$ & $82.50 \%$ & $90.00 \%$ \\
\hline Rata-rata Persentase Aktivitas Guru & $69.35 \%$ & $81.55 \%$ & $88.69 \%$ \\
\hline
\end{tabular}

Berdasarkan tabel 3, terlihat aktivitas guru dalam proses pembelajaran menulis permulaan melalui metode Struktural Analitik Sintetik meningkat dari siklus I-III. Peningkatan rata-rata keberhasilan setiap tahap pembelajaran dapat dijabarkan sebagai berikut. Pertama, tahap pendahuluan pada siklus I $71.88 \%$, siklus II $81.25 \%$ dan siklus III 93.75\%. Kedua, tahap inti pada siklus I $66.25 \%$, siklus II $81.25 \%$ dan siklus III 85\%. Ketiga, tahap penutup pada siklus I 69,35\%, siklus II 82.50\%, dan siklus III $90 \%$. 
Tabel 4. Hasil Observasi Aktivitas Siswa dalam Pembelajaran Menulis Permulaan

\begin{tabular}{lccc}
\hline \multirow{2}{*}{ Aspek } & \multicolumn{3}{c}{ Penilaian Aktivitas Siswa } \\
\cline { 2 - 4 } & Siklus I & Siklus II & Siklus III \\
\hline Respon & $57.75 \%$ & $73.50 \%$ & $80.75 \%$ \\
\hline Antusiasme & $60.50 \%$ & $76.50 \%$ & $82.50 \%$ \\
\hline Keaktifan & $62.30 \%$ & $76 / 25 \%$ & $84.00 \%$ \\
\hline Rata-rata Persentase Aktivitas Siswa & $60.33 \%$ & $75.42 \%$ & $82.42 \%$ \\
\hline
\end{tabular}

Berdasarkan tabel 4, terlihat aktivitas siswa pada proses pembelajaran menulis permulaan melalui metode Struktural Analitik Sintetik meningkat pada setiap aspek yang diamati. Peningkatan rata-rata keberhasilan setiap tahap pembelajaran dapat dijabarkan sebgai berikut. Pertama, aspek respon pada siklus I 57.75\% berkualifikasi cukup, siklus II $73.50 \%$ berkualifikasi baik dan siklus III $80.75 \%$ berkualifikasi sangat baik. Kedua, aspek antusisme pada siklus I $60.50 \%$ berkualifikasi cukup, siklus II $76.50 \%$ berkualifikasi baik dan siklus III $82.50 \%$ berkualifikasi sangat baik. Ketiga, aspek keaktifan pada siklus I $62.75 \%$ berkualifikasi cukup, siklus II $76.25 \%$ berkualifikasi baik dan siklus III $84 \%$ berkualifikasi sangat baik.

Tabel 5. Hasil Penilaian Keterampilan Menulis Permulaan

\begin{tabular}{lccc}
\hline \multicolumn{1}{c}{ Aspek } & \multicolumn{2}{c}{ Penilaian Aktivitas Siswa } \\
\cline { 2 - 4 } & Siklus I & Siklus II & Siklus III \\
\hline Kerapian & $48.75 \%$ & $66.50 \%$ & $78.50 \%$ \\
\hline Kelengkapan & $55.00 \%$ & $69.25 \%$ & $81.25 \%$ \\
\hline Ketepatan & $57.00 \%$ & $70.25 \%$ & $80.00 \%$ \\
\hline Rata-rata Persentase Keterampilan Menulis Permulaan Siswa & $53.58 \%$ & $68.66 \%$ & $79.92 \%$ \\
\hline
\end{tabular}

Berdasarkan tabel 5, keberhasilan keterampilan menulis permulaan melalui metode Struktural Analitik Sintetik meningkat pada setiap indikator dari setiap siklus. Berdasarkan gambar 5, peningkatan rata-rata persentase keberhasilan setiap indikator dapat dijabarkan sebagai berikut. Pertama, kerapian tulisan pada siklus I $48.75 \%$ berkualifikasi kurang, siklus II $66.50 \%$ berkualifikasi cukup dan siklus III $78.50 \%$ berkualifikasi baik. Kedua, kelengkapan tulisan pada siklus I 55\% berkualifikasi cukup, siklus II $69.25 \%$ berkualifikasi baik dan siklus III $81.25 \%$ berkualifikasi sangat baik. Ketiga, ketepatan tulisan pada siklus I 57\% berkualifikasi cukup, siklus II $70.25 \%$ berkualifikasi baik, dan siklus III $80 \%$ berkualifikasi sangat baik.

\section{PEMBAHASAN}

Proses pembelajaran keterampilan menulis permulaan melalui metode Struktural Analitik Sintetik dilaksanakan berdasarkan tiga tahapan kegiatan pembelajaran, yaitu tahap pendahuluan, tahap inti, dan tahap penutup. Kegiatan pendahuluan dilakukan sesuai dengan perencanaan yang telah disusun dan dilaksanakan pada siklus I, II, dan III. Kegiatan pendahuluan meliputi (1) salam dan doa, (2) melakukan presensi, (3) melakukan apersepsi, dan (4) menyampaikan kompetensi yang akan dicapai dalam pembelajaran. Kegiatan-kegiatan tersebut berkaitan erat dengan aktivitas membuka pembelajaran. Aktivitas membuka pembelajaran harus dilakukan dengan baik dengan tujuan untuk menyiapkan siswa belajar dengan kondisi dan suasana kelas yang baik. Selain itu, kegiatan apersepsi dilakukan untuk mengaitkan pengetahuan yang sudah dimiliki siswa dengan pengetahuan baru yang akan dipelajari siswa. Selama pembelajaran dari siklus I, II, dan III kegiatan pembukaan pembelajaran dilaksanakan dengan baik. Kegiatan apersepsi pada setiap pembelajaran dilakukan secara beragam, seperti dengan menyanyikan lagu, menampilkan gambar atau video pembelajaran.

Kegiatan pembelajaran pada tahap inti dilakukan sesuai dengan perencanaan yag telah disusun dan dilaksanakan pada siklus I, II, dan III dengan langkah pembelajaran merujuk pada Solchan.,dkk. Sementara itu, kegiatan pembelajaran pada tahap penutup, meliputi (1) pemberian pujian dan reward, (2) menyampaikan kesan dan kesimpulan materi dan (3) pemberian motivasi untuk menulis. Pemberian pujian dan reward dalam suatu pembelajaran sangatlah penting. Hal ini memberikan semangat, penguatan serta dorongan bagi siswa untuk belajar dengan tekun. Pemberian hadiah dan reward dapat membuat siswa termotivasi melakukaan kegiatan-kegiatan untuk mencapai tujuan pembelajaran. Penggunaan kata-kata pujian, seperti 'bagus sekali', 'hebat', 'luar biasa'; memberikan tepuk tangan; atau pemberan snack di setiap akhir siklus sangat diperlukan. Penggunaan kata-kata pujian dapat membantu siswa yang memiliki pencapaian yang rendah dan membuat siswa lebih bersemangat dalam melakukan sesuatu dapat dilakukan dengan pemberian motivasi berupa pujian-pujian kepada siswa (Slavin, 2008). Pemberian pujian dan reward kepada siswa merupakan contoh dalam memberikan penguatan dan dorongan kepada siswa dalam pembelajaran. Adapun kegiatan kegiatan merefleksikan pengalaman belajar dan pemberian motivasi yang juga sangat penitng untuk siswa. 
Berdasarkan tahapan kegiatan pembelajaran menulis permulaan melalui metode Struktural Analitik Sintetik diperoleh data tentang peningkatan proses dan peningkatan hasil keterampilan menulis permulaan melalui metode Struktural Analitik Sintetik. Data peningkatan proses berupa peningkatan hasil observasi aktivitas siswa dan guru pada proses pembelajaran menulis permulaan melalui metode Struktural Analitik Sintetik, sedangkan data peningkatan hasil berupa keterampilan menulis permulaan siswa melalui metode Struktural Analitik Sintetik. Peningkatan proses dan hasil keterampilan menulis permulaan melalui metode Struktural Analitik Sintetik dirangkum pada grafik gambar 1, 2, dan 3.

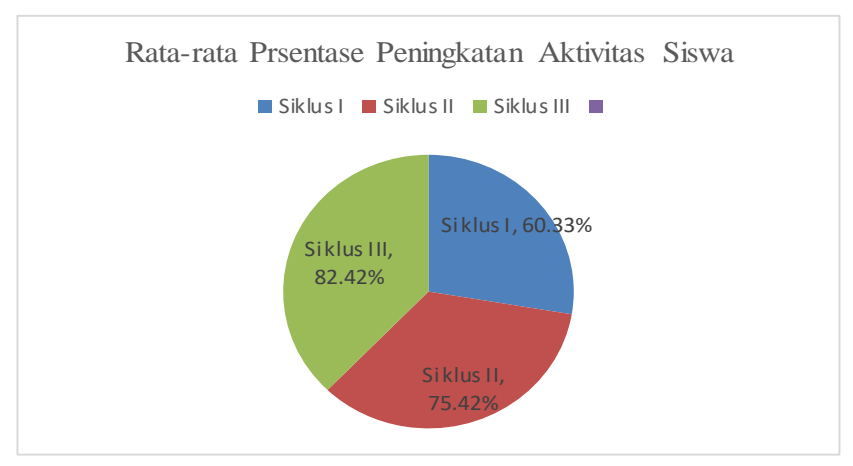

Gambar 1. Peningkatan Hasil Aktivitas Siswa dalam Pembelajaran Menulis Permulaan melalui Metode SAS

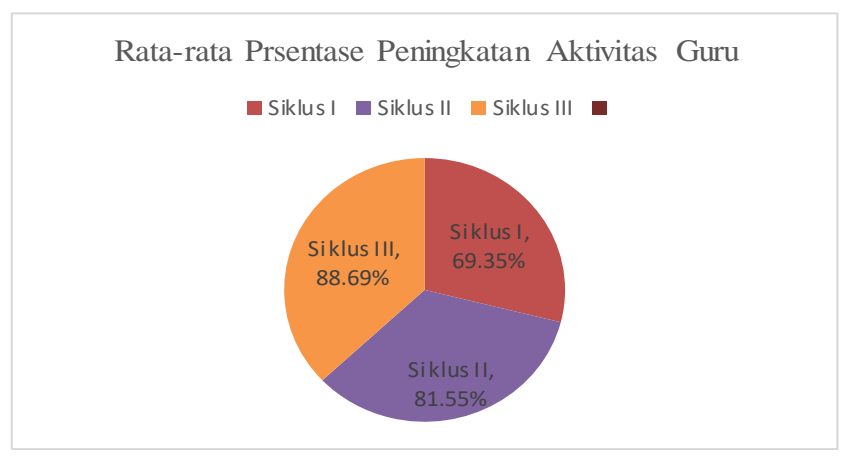

\section{Gambar 2. Peningkatan Hasil Aktivitas Guru dalam Pembelajaran Menulis Permulaan melalui Metode Struktural Analitik Sintetik}

Berdasarkan gambar 1, terlihat adanya peningkatan aktivitas siswa pada proses pembelajaran menulis permulaan melalui metode Struktural Analitik Sintetik. Pada siklus I perolehan rata-rata $60.33 \%$, meningkat pada siklus II menjadi $75,42 \%$ dan meningkat lagi pada siklus III menjadi $82.42 \%$. Kualifikasi setiap siklus juga meningkat dari berkualifikasi cukup pada siklus I meningkat berkualifikasi baik pada siklus II dan meningkat lagi berkualifikasi sangat baik pada siklus III. Berdasarkan gambar 2, terlihat adanya peningkatan aktivitas guru yang diperoleh dalam proses pembelajaran menulis permulaan melalui metode Struktural Analitik Sintetik. Prolehan rata-rata pada siklus I 69.35\%, kemudian meningkat pada siklus II $81.55 \%$ dan meningkat lagi pada siklus III $88.69 \%$. Kualifikasi aktivitas guru juga meningkat yaitu pada siklus I berkualifikasi baik, sedangkan pada siklus II dan III berkualifikasi sangat baik.

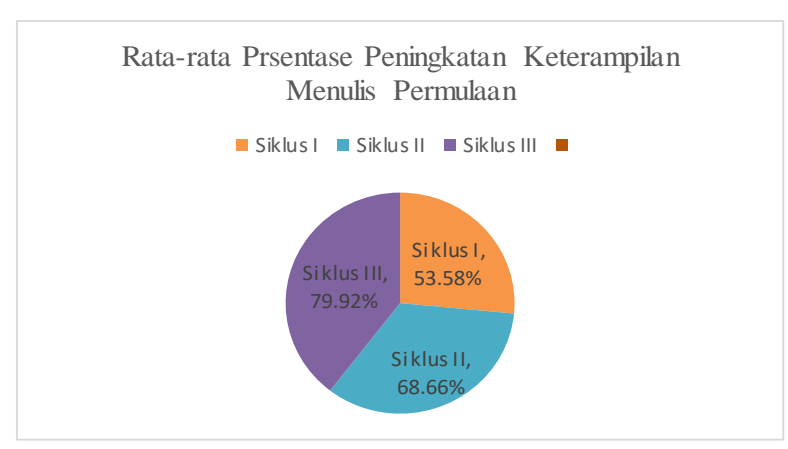

Gambar 3. Peningkatan Hasil Keterampilan Menulis Permulaan Siswa melalui Metode Struktural Analitik Sintetik 
Berdasarkan gambar 3, terlihat peningkatan keterampilan menulis permulaan melalui metode Struktural Analitik Sintetik pada setiap siklus. Rata-rata persentase keberhasilan pada siklus I sebesar $53.58 \%$ berkualifikasi kurang, siklus II meningkat menjadi $68.67 \%$ berkualifikasi baik dan siklus III meningkat lagi menjadi $79.92 \%$ berkualifikasi baik. Peningkatan proses dan hasil keterampilan menulis permulaan melalui metode Struktural Analitik Sintetik yang dipaparkan dalam grafik dapat membuktikan bahwa penerapan metode Struktural Analitik Sintetik dapat meningkatkan keterampilan menulis siswa SD Katolik In'ane.

Penelitian ini juga didukung oleh beberapa penelitian yang telah dilakukan sebelumnya yang relevan yaitu Sumarni (2000) dengan hasil penelitiannya menunjukkan bahwa penerapan metode Struktural Analitik Sintetik melalui media gambar dapat meningkatkan kemampuan membaca permulaan siswa kelas I SD. Penelitian lain juga dilakukan oleh Saonah (2018) dengan hasil penelitian menunjukkan bahwa penggunakan media gambar dapat meningkatkan kemampuan membaca dan menulis peserta didik di kelas I Sekolah Dasar Negeri 222 Pasir Bogor Kecamatan Rancasari kota Bandung. Selanjutnya hasil penelitian yang dilakukan oleh Nuryamah (2016) menunjukkan bahwa penerapan media gambar dan papan bergaris dapat meningkatkan proses pembelajaran dan hasil belajar siswa kelas II SDN Palasari pada materi menulis permulaan tegak bersambung dalam melengkapi cerita rumpang. Penelitian lain yaitu Halimah (2014). dengan hasil penelitian yaitu penerapan metode CIRC dapat meningkatkan kemampuan membaca dan menulis di SD/MI. Selanjutnya, hasil penelitian oleh Janawati (2013) menunjukkan bahwa terdapat pengaruh implementasi pembelajaran kartu kata dalam permainan domino terhadap peningkatan kemampuan membaca menulis permulaan siswa. Adapun hasil penelitian oleh Kurniaman (2017) menunjukkan bahwa penerapan metode Struktural Analitik Sintetik dapat meningkatkan keterampilan membaca permulaan di kelas I SDN 79 Pekanbaru.

\section{SIMPULAN}

Keterampilan menulis permulaan siswa setelah dibelajarkan menggunakan metode SAS meningkat pada setiap siklus. Hal ini ditunjukkan dengan hasil penelitian yang telah dilakukan di SD Katolik In'ane di mana rata-rata persentase aktivitas siswa pada siklus I $60.33 \%$ berkualifikasi cukup, meningkat pada siklus II $75.42 \%$ berkualifikasi baik dan meningkat pada siklus III $82.42 \%$ berkualifikasi sangat baik. Perolehan rata-rata persentase keberhasilan aktivitas guru juga mengalami peningkatan yaitu pada siklus I $69.35 \%$ berkualifikasi cukup kemudian mengalami peningkatan pada siklus II $81.55 \%$ dan siklus III 88.69\% dengan kualifikasi sangat baik. Adapun rata-rata persentase keberhasilan keterampilan menulis permulaan siswa pada siklus I 53.58\% berkualifikasi cukup mengalami peningkatan pada siklus II $68.67 \%$ dan siklus III $79.92 \%$ dengan kualifikasi baik.

Pembelajaran menulis permulaan melalui metode Struktural Analitik Sintetik dapat ditingkatkan dengan pengelolaan kelas dan alokasi waktu yang baik sehingaa waktu dalam pembelajaran harus lebih efektif serta guru harus kreatif dan inovatif karena metode pembelajaran ini melibatkan siswa aktif. Penggunaan media pembelajaran juga harus diperhatikan dan disesuaikan dengan pelajaran yang diajarkan agar tidak mengurangi tujuan dan manfaat dari media tersebut. Penelitian ini juga dapat dilanjutkan dengan meneliti variabel terkait lain, misalnya keterampilan membaca permulaan.

\section{DAFTAR RUJUKAN}

Bua, T. M. (2016). Peningkatan Keterampilan Menulis Permuaan dengan Teknik Scaffolding Berbasis Cerita Bergambar di Kelas I SDN Purwantoro 6 Kota Malang. Tesis tidak diterbitkan. Universitas Negeri Malang, Malang.

Dalman. (2016). Keterampilan Menulis. Jakarta: Rajawali Pers.

Dewi, C. (2018). Penggunaan Metode SAS (Struktural Analitik Sintetik) dalam Pembelajaran Bahasa Indonesia Menulis Permulaan Siswa Sekolah Dasar. Bahastra, 38(1), 8-13.

Sumarni, E. (2000). Penerapan Metode Struktural Analitik Sintetis (SAS) melalui Media Gambar untuk Meningkatkan Kemampuan Membaca Permulaan pada Siswa Kelas I Sekolah Dasar. Jurnal Pendidikan Dasar, 2(1).

Halimah, A. (2014). Metode Cooperative Integrated Reading and Composition (CIRC) dalam Pembelajaran Membaca dan Menulis di SD/MI. Auladuna Jurnal Pendidikan Dasar Islam, 1(36), 27-35.

Janawati, D. P. A. Sudiana, I. N., \& Dantes, N. (2013). Pengaruh Implementasi Pembelajaran Kartu Kata dalam Permainan Domino terhadap Peningkatan Kemampuan Membaca Menulis Permulaan Siswa. Jurnal Pendidikan Dasar, 3(1).

Kemmis, S., McTaggart, R., \& Nixon, R. (2014). The Action Research Planner (doing Critical Participatory Action Research). Singapura: Springer.

Kurniaman, O. (2017). Metode Membca SAS (Struktural Analitik Sintetik) dalam Meningkatkan Keterampilan Membaca Permulaan di Kelas I SDN 79 Pekanbaru. Jurnal Pendidikan Guru Sekolah Dasar, 5(2), 149-157.

Lisnawati, L., \& Muthmainah, M. (2019). Efektivitas Metode SAS (Struktur Analitik Sintetik) Dalam Meningkatkan Keterampilan Membaca bagi Anak Lambat Belajar (Slow Learner) di SDN Demangan. Jurnal Psikologi Integratif, 6(1), 81.

Mustikowati, D. (2016). Meningkatkan Semangat dan Menulis Siswa Sekolah Dasar dengan Permainan Kata Bersambut. BRILIANT: Jurnal Riset dan Konseptual, 1(1), 16-23.

Nuryamah, I. (2016). Upaya Meningkatkan Keterampilan Menulis Permulaan dalam Melengkapi Cerita Rumpang Menggunakan Media Gambar dan Papan Bergaris. Pena Ilmiah, 1(1), 761-770. 
667 Jurnal Pendidikan, Vol. 4, No. 5, Bln Mei, Thn 2019, Hal 660-667

Patty, R. 2015. Pengembangan Model Induktif Kata Bergambar pada Pembelajaran Menulis Permulaan di Kelas II SD. Sekolah Dasar Kajian Teori dan Praktik Pendidikan, 24(2), 172-179.

Rusman. (2014). Model-model Pembelajaran:Mengembangkan Profesionalisme Guru. Jakarta: Raja Grafindo Persada.

Saddhono, K \& Slamet, Y. (2014). Pembelajaran Keterampilan Berbahasa Indonesia: Teori dan Aplikasi. Yogyakarta: Graha Ilmu.

Saonah, S. (2018). Meningkatkan Kemampuan Membaca dan Menulis Permulaan dengan Media Gambar di Kelas I SD Negeri 222 Pasir Pogor. Elementaria Edukasia, 1(1), 101-107.

Slavin, R. E. (2008). Psikologi Pendidikan: Teori dan Praktik Edisi Kedelapan. Jakarta: PT Indeks.

Solchan T. W., Mulyati, Y., Syarif, M., Yunus, M., Werdiningsih, E., Pramuki, E. B., Badriyah, R., \& Setiawati, L. (2014). Pendidikan Bahasa Indonesia di SD. Banten: Universitas Terbuka.

Sugiyono. (2016). Metode Penelitian Pendidikan (Pendekatan Kuantitatif, Kualitatif, dan R \& D). Bandung: Alfabeta.

Hidayah, W. (2016). Peningkatan Keterampilan Menulis Permulaan Menggunakan Buku Harian Siswa Kelas I A SDN Plebengan Sidomulyo Bantul Tahun 2015/2016. Basic Education, 5(28), 2713-2720. 